\title{
ON GELLMAN'S ATTEMPTED RESCUE
}

\author{
STEPHEN MAITZEN
}

\author{
Acadia University
}

I thank Jerome Gellman for his critique of my recent article "Ordinary Morality Implies Atheism." In that article, I argued that traditional theism threatens ordinary morality by relieving us of any moral obligation to prevent horrific suffering by innocent people even when we easily can. Gellman attempts to rescue that moral obligation from my charge that theism destroys it. I believe his attempted rescue fails.

Gellman begins by quoting the main principle on which my argument depends, the principle sometimes called "theodical individualism" that I abbreviated with the initials "TI":

(TI) Necessarily, God permits undeserved, involuntary human suffering only if such suffering ultimately produces a net benefit for the sufferer.

He then correctly notes that theism-the proposition that God existsand TI together imply (to use Gellman's numbering)

(3a) Necessarily, all undeserved, involuntary human suffering ultimately produces a net benefit for the sufferer.

However, Gellman gives reasons to reject the claim in my argument that (3a) implies (again, his numbering)

(3c) We never have a moral obligation to prevent undeserved, involuntary human suffering.

${ }^{1}$ Jerome Gellman, "On God, Suffering, and Theodical Individualism," European Journal for Philosophy of Religion 2:1 (2010): 187-191, replying to Stephen Maitzen, "Ordinary Morality Implies Atheism," European Journal for Philosophy of Religion 1:2 (2009): 107-26. Further references to these works will cite author and page number only. 
That is, he claims to preserve our ordinary moral obligation even if theism and TI are true.

I'll argue that the reasons Gellman gives fail to answer my challenge, because they're implausible reasons on two independent grounds. First, his reasons confuse cases in which God's permission of suffering is justified by some benefit to the sufferer (cases that therefore are relevant to TI) with cases in which God confers a benefit in an attempt to compensate the sufferer (cases that therefore aren't relevant to TI). Second, his critique assumes that God might face constraints that there's no good reason to think a perfect being could face.

\section{COMPENSATION VS. JUSTIFICATION (AGAIN)}

Gellman writes, "Let P be any person that I allow to endure suffering, instead of preventing the suffering. And let $S$ be the particular instance of suffering that $\mathrm{P}$ undergoes." His critique of my argument then asserts that the following propositions are "not implausible, granting God's existence and perfect goodness":

(G1) God has so created the world that God is able to produce for P a degree, $\mathrm{D}$, of good for $\mathrm{P}$ that will make P's existence worthwhile.

(G2) God will bring about D for P. This will not be in the form of compensation but a result produced by P's history.

(G3) D is a maximal degree of good that God can produce for P.

(G4) God will bring about D for P whether P suffers (this particular) $S$ or not. If $P$ suffers $S$, then God will produce a net good from $S$ for $\mathrm{P}$, to offset the evil of $\mathrm{S}$ in order to reach $\mathrm{D} .^{2}$

Whether or not Gellman's propositions are plausible, at least two of them are simply irrelevant to my argument. In my article, I took pains to distinguish justification from mere compensation, and in doing so I quoted Christian philosopher Eleonore Stump's version of the idea that TI tries to capture: "if a good God allows evil," says Stump, "it can only be

${ }^{2}$ Gellman, 188. 
because the evil in question produces a benefit for the sufferer and one that God could not produce without the suffering." ${ }^{3}$ then wrote,

Like Stump's use of it, TI's use of the word "produces" is significant, because otherwise we allow that God's mere compensation of the sufferer-say, in a blissful afterlife - can justify God's permission of suffering even if the suffering bears no necessary connection to the good that compensates for it. Without such a connection, the good may compensate for the suffering but can't morally justify God's permission of it. ${ }^{4}$

Gellman's proposition G2 gestures at the difference between compensation and justification. However, I find G2's claim that God brings about D "as a result produced by P's history" mysterious. If $\mathrm{D}$ is a result produced by P's history, how is it that God brings about $\mathrm{D}$ ? Is it because God brings about P's history? If so, then God exercises a degree of "meticulous providence" that many theologians would reject. In the end, however, I can only guess at the meaning of G2.

More important, neither G2 nor G4 ever says or even hints that $S$ is necessary for, or the best means of, God's securing D for P. As Stump seems to recognize, when we ask whether someone's permission of suffering is justified by its relationship to some benefit for the sufferer, we ask (in part) whether the permission is necessary, or if not strictly necessary then optimal, for securing the benefit. ${ }^{5}$ Nothing in G2 or G4 requires or even suggests an affirmative answer to that question in the case of God, P, S and D. On the contrary, G4 says that God will secure D for

\footnotetext{
${ }^{3}$ Eleonore Stump, "The Problem of Evil," Faith and Philosophy 2 (1985): 392-423; 411-12.

${ }^{4}$ Maitzen, 110, emphasis in original. I continued: "Consider an analogy to our ordinary moral practice. My paying you money after harming you may compensate for my harming you, but it doesn't justify my harming you. Only something like the necessity of my harming you in order to prevent your harming me or an innocent third party has a chance of justifying my behavior: some necessary connection must hold between the harm and the benefit."

${ }^{5}$ See also Maitzen, 115, again quoting Stump; the fuller quotation from Stump reads, "other things being equal, it seems morally permissible to allow someone to suffer involuntarily only in case doing so is a necessary means or the best possible means in the circumstances to keep the sufferer from incurring even greater harm" ("Providence and the Problem of Evil," in Christian Philosophy, ed. Thomas P. Flint [Notre Dame, Indiana: University of Notre Dame Press, 1990], 51-91; 66).
} 
P regardless of whether God permits $S$ to occur, in which case it's hard to see how $\mathrm{D}$ plays any role in justifying God's permission of $S$ in particular. In light of this problem, it won't do simply to stipulate, as G2 does, that God's bringing about $\mathrm{D}$ for $\mathrm{P}$ isn't merely compensation for S, especially when G4 encourages the suspicion that it is merely compensation. G2 and G4 are, so far as I can see, simply irrelevant to whether God is justified in permitting $S$ and hence irrelevant to the implications of TI.

\section{A HAMSTRUNG GOD?}

The final proposition that Gellman offers as "not implausible" is quite a mouthful even though he describes it as "a claim about our ordinary morality":

(G5) One can morally allow $\mathrm{P}$ to suffer $\mathrm{S}$ if and only if the net benefit to $P$ from allowing $S$ will far outweigh $S$, and either: (a) the net benefit to $\mathrm{P}$ from allowing $\mathrm{S}$ will be far greater than the good that will be P's if one prevents $S$, or (b) the net benefit to $\mathrm{P}$ from one's allowing $S$ will not be less than the good that will be P's if one prevents $\mathrm{S}$, and allowing $\mathrm{S}$ will significantly increase the net good in the world.

While one might doubt that something as complex as G5 does in fact govern our ordinary moral reasoning, let's grant that it does. Gellman says that G5 preserves the moral obligation that I claim theism and TI jointly threaten, because according to G5 we can be obligated to prevent $S$ even if God's permission of $S$ satisfies TI's requirement of a net benefit to P. For, unlike TI, G5 requires that the benefit to $\mathrm{P}$ not just outweigh but far outweigh S, and G5 imposes a further, disjunctive condition on top of that.

If G5 is so plausible, does it also bind God? Gellman says it does: "G5 obligates God no less than it does mere mortals. And since God is a perfect being God will faithfully fulfill the dictate of G5."' In that case, it would certainly appear, God is justified in permitting only the suffering

${ }^{6}$ Gellman, 191. 
that G5 justifies us in permitting. If so, however, then we don't have the moral obligation that Gellman wants to rescue. Because God is perfect in knowledge, power, and goodness, any suffering that occurs is suffering that God permits (else he lacks perfect power or perfect knowledge) and is justified in permitting (else he lacks perfect goodness). So if we're justified in permitting $S$ whenever God is justified in permitting $S$, we're always justified in permitting $\mathrm{S}$. There goes morality.

Remarkably enough, Gellman tries to avoid this unwanted implication by having God plead other commitments. According to Gellman, God is stuck with

juggling God's obligations to all human persons.... All human beings are turned to God with an equal claim to a personal maximal net benefit, everything else being equal. Thus, God's obligations to others besides $P$ are of vastly greater dimensions than that of any human being to other persons. [Hence] God might be justified in allowing suffering. . .in vastly many cases, while humans have relatively sparse permission to do so. ${ }^{7}$

Thus Gellman retracts his earlier assertion that G5 obligates God and that God "will faithfully fulfill the dictate of G5," for he allows God to opt out of G5 if other commitments prevent God from honoring it. ${ }^{8}$

I can't see how a perfect being could be hamstrung in the way Gellman suggests. In Gellman's story, God isn't obligated to prevent $S$ because God has commitments to others besides P, commitments that force God to allow $S$ (or else somehow justify God's allowing $S$ even though they don't force it). Nevertheless, he says, we can be obligated where God isn't, because we don't have God's excuse: unlike God, we don't have an equal obligation toward every human being. So God sometimes needs us to prevent suffering by $\mathrm{P}$ that God himself can't prevent without failing in his duty to someone other than P. I can't how see a perfect being could find itself in such a pickle. I often need a little help from my friends: "Can

\footnotetext{
${ }^{7}$ Gellman, 191, emphasis in original.

${ }^{8}$ Gellman writes that "the suffering God allows a person to endure is such that God allows it either: (i) so as to produce for that person a degree of good that is maximal for that person and also satisfies the conditions of G5, or: (ii) because allowing it follows from God's juggling God's obligations to all human persons" (191). I interpret (ii) as the "out" clause Gellman offers God, because (ii), unlike (i), makes no mention of God's satisfying G5.
} 
you pick up Jack? I promised him a ride, but I also promised to pick up Jill elsewhere at the same time, and I can't be in two places at once." But Gellman claims to be describing the supremely independent God of classical monotheism, not a limited being like me.

Gellman faces a dilemma: Does God honor his obligation to P under $\mathrm{G} 5$ or not? If yes, then allowing $S$ confers a benefit to $P$ that far outweighs $S$ (and achieves other good things too), in which case, as I argued in my article, we have no obligation to prevent S. If no, then why doesn't God honor his obligation to P? Presumably because God can't honor it and also honor his obligations to others besides $\mathrm{P}$, which is exactly the situation I face in my example. It doesn't matter how God ends up in my predicament, since it's implausible enough to think that God could end up in my predicament.

Gellman might reply that we can't know that a perfect God isn't hamstrung by constraints that force God to permit $S$ when he'd rather prevent it. But surely the burden of proof rests with whoever suggests that such limitations apply to a perfect God. In any case, I hope nobody offers the hoary suggestion that God's constraints include a commitment never to interfere with our libertarian free will, a suggestion I criticized in my article because it contradicts the biblical account of God's conduct, overstates the value we actually attach to free will, and otherwise fails to jibe with ordinary morality. 